\title{
Scale of Teaching Strategies for Collaborative Learning: Design, Validation and Evaluation of Its Psychometric Properties in High School Education
}

\author{
Magaly Cárdenas Rodríguez* 두, Luz Marina Méndez Hinojosa, César Alejandro Ortiz Páez \\ Universidad Autónoma De Nuevo León, San Nicolas de los Garza, Mexico \\ Email: *magalycardz@gmail.com
}

How to cite this paper: Rodríguez, M. C., Hinojosa, L. M. M., \& Páez, C. A. O. (2019). Scale of Teaching Strategies for Collaborative Learning: Design, Validation and Evaluation of Its Psychometric Properties in High School Education. Psychology, 10, 256-272.

https://doi.org/10.4236/psych.2019.102019

Received: January 12, 2019

Accepted: February 17, 2019

Published: February 20, 2019

Copyright $\odot 2019$ by author(s) and Scientific Research Publishing Inc. This work is licensed under the Creative Commons Attribution International License (CC BY 4.0).

http://creativecommons.org/licenses/by/4.0/

\begin{abstract}
Most of the educational programs worldwide have focused on the diverse competences of the students, but in all of them, collaborative learning plays an important role. It is likely that many institutions are unaware of the teaching strategies that can produce collaborative learning in the classroom. Therefore, the present study aimed to design and evaluate the psychometric properties of a scale that examined the frequency of use of teaching strategies that led to collaborative learning in students. Nine subscales were designed, each one measuring a different strategy, these were evaluated by expert judgment and subsequently, they were applied to a sample of 200 high school teachers. Based on the data obtained, it is possible to provide evidence, through exploratory factor analysis and Cronbach's alpha, of the instrument's validity and reliability.
\end{abstract}

\section{Keywords}

Teaching Strategies, Collaborative Learning, High School Education

\section{Introduction}

Education has been throughout history as one of the main pillars that sustains the development of our society. Education allows people to extend their knowledge and understanding of the environment that surrounds them. Being such an important area, it is logical that many organizations deepen educational issues in different social environments, as this contributes to increasing production and the scope of knowledge. In this era where cultural, social and technological changes are advancing in shorter periods, schools in all educative levels 
need to provide the right tools, so that students can develop the curiosity, creativity, self-regulation, collaborative learning and many other skills that are necessary to cope with the changes in their environment (Khan, 2012).

In international context, some organizations like the United Nations Organization (UN), the Organization for Economic Cooperation and Development (OECD), the United Nations Educational, Scientific and Cultural Organization (UNESCO) and the United Nations Economic Commission for Latin America and the Caribbean (ECLAC) put some statements about what is to be desirable in education for the future: goals, programs and the importance to achieve better opportunities. In general terms they provide work guidelines from elementary to higher education about what need to be the focus in education. The programs are based on the particular needs of each society, from infrastructure to the characteristics of the students; with this, they can be prepared for the problems they might face in the future (ECLAC, 2018; OECD, 2017; UN, 2015; UNESCO, 2016).

Is it worth mentioning that in Mexico some of the most important universities are aware of this recommendation from international organizations? They acknowledge the importance and the impact this could have in the outcomes of education because some of them cover high school education to higher education; with this they can shape a better opportunities for the students in their academic goals (BUAP, 2007; IPN, 2004; ITESM, 2018; UABC, 2013; UANL, 2008). From the vast majority of factors that involve the education process in education, we believe the abilities within the student are the crucial factor of their academic success, like curiosity, creativity, self-regulation as a few of the skills that could help the students with their learning process; in this document we focus on the particular aspect of collaborative learning and how teachers can evaluate this particular skill in their students. For this reason, the main objective of this study is to design and evaluate the psychometric properties of a scale that examines the frequency of use of teaching strategies that lead to collaborative learning in students.

\section{Basic Concepts}

Teaching strategies in high school education have changed drastically in recent years, although there are still some teachers who use traditional strategies that could lead to less effective learning in the students. Participation and interaction among educational actors, nowadays more and more are struggling with the application of strategies that provoke reflection and the joint construction of knowledge and teachers need to provide guidance in student so they can develop the required skills to ensure their academic goals (Khan, 2012).

In 2007 Schroeder, Scott, Toison, Huang and Lee, cited by Ramírez Montoya (2013), presented research data regarding the most effective teaching strategies in science, found that the strategies with which students performed better were: question-answer, research, evaluation, significant contexts, use of technology and collaborative learning. 
In various studies, both theoretical and empirical, it is beneficial to bring together a group of students who are assigned activities that involve mutual assistance and interaction between peers, which through dialogue and consensus, transmit, discuss, modify and transform the knowledge (Noh \& Yusuf, 2018), highlighting the fact that peers may have expertise or authority on some issues. The learning that is reproduced in the classrooms from the above is what is known as collaborative learning. Collaborative learning between peers let them choose their topic and engage their commitment to achieve their academic goals (Maldonado Pérez, 2008). Also, the use of collaborative learning is now day's extended in virtual environment, proven a useful tool in learning process through social networks (Marín-Juarros, Negre, \& Pérez, 2014).

\subsection{Circle of Ideas}

It is a variation of the brainstorming technique in which students generate them, but do not elaborate, explain, evaluate or question ideas. The members of the groups respond in turn to a question with a word, expression or short statement. The order of the answers is organized by passing from one student to another until everyone has had the opportunity to speak.

\subsection{Conversations Groups}

They are teams of between four and six students that are formed quickly to answer questions related to the topic. The purpose of the dialogue is to exchange ideas and these are effective to generate information in a short time (De Oca Recio \& Manchado Ramirez, 2011).

\subsection{Critical Debates}

In this strategy the students select an opposite view of their own in one specific topic. Then they form teams and dialogue, present and defend the issue in front of the opposing team (Martinez Lirola, Catala Cobos, \& Diaz Soria, 2013). Preparing, participating and listening to the debates have many benefits, can increase motivation, strengthen research skills, promote critical thinking and deepen from many points of view.

\subsection{Role Playing Game}

A simulated situation is created in which students deliberately represent or assume personalities or identities that they would not normally admit. It facilitates an environment of action for students to experience the emotional and intellectual responses of an assumed identity or an imagined circumstance; this facilitates students learning process (Chan, 2012). In addition, role play can be fundamental for the acquisition of different skills and attitudes in the students (Martínez-Riera, Sanjuán-Quiles, Cibanal-Juan, \& Pérez-Mora, 2011). For some students, role playing game helps in their leaning process but some may experience difficulties based on their academics goals, if they just want to reproduce 
or memorize rather than understand a concept (Spiers et al., 2014).

\subsection{Test Teams}

Students work in teams in order to prepare for the examinations called by the teacher and perform them, first answer the exam individually and then in a group. By working together to prepare for the exam, students will help each other to deepen the understanding of content.

\subsection{Puzzle}

Students work in small groups in order to develop their knowledge on a particular topic. Students must master a certain subject and pass it on to different teams. First they are part of a "puzzle" or team and transmit the content. Once understood by his teammates they move on to the next team and form a new "puzzle". It is helpful in motivating students to take on the responsibility of learning something well enough to teach it to their peers. It also offers the opportunity for each student to become the center of attention (Reeve \& Jang, 2006).

\subsection{Case Studies}

The student teams review a written study of a real-life scenario that contains a problematic situation related to the area of knowledge (De Oca Recio \& Manchado Ramirez, 2011). These cases include a brief history of how the situation has developed and present a problem faced by a key character on the stage (Díaz De Salas, Mendoza Martínez, \& Porras Morales, 2011). Team members apply concepts from the subject to identify, evaluate alternative approaches to solving the problem and provides a better understanding through experience (Álvarez Álvarez \& San Fabián Maroto, 2012).

\subsection{Structured Problem Solving}

This strategy provides students with a procedure for solving a complex, content-related problem over a specific period of time. All members of the group have to agree on the solution and must be able to explain both the response and the strategy used to solve the problem. This technique helps students by dividing the process into concrete steps. Students learn to identify, analyze and solve problems in an organized way.

\subsection{Collaborative Writing}

Students work in groups of two or three to write an article. Each student participates in each sentence of the writing process: brainstorming, obtaining and organizing information and writing, reviewing and correcting the writing. Working together can help you learn and more effectively complete the writing phases of writing and produce better text with more grammatical accuracy and complexity (Storch, 2005). 


\section{Methodology}

In this study we choose a quantitative approach aimed to design a set of subscales with evidence of validity and reliability, which measure the frequency of use of teaching strategies that lead to collaborative learning in the students, with the specific objectives of:

1) Design a set of subscales with Likert-type items where each one evaluates the frequency of use of a teaching strategy in the classroom.

2) Analyze the factor structure of each subscale.

3) Determine the inter-item reliability of each subscale.

\subsection{Participants}

The sample (Table 1) selected for this research was composed of 200 teachers from different public high schools in Mexico (de que materias en específico, de que estados de la república y si se tienen las cantidades por estado).

The only criterion of inclusion was that teachers had at least one-year teaching experience in any field.

\subsection{Instruments}

The Teaching Strategies Scale for Collaborative Learning or EEDAC (See Appendix) (his acronym in Spanish) was designed using the theoretical frame of reference Barkley, Cross and Major (2005). The scale consists of 80 items integrated in 9 subscales; each of which contains indicators of the appropriate application of a teaching strategy that promotes collaborative learning. The subscales with their respective number of items are the following: Circle of Ideas Wheel (10), Conversation Groups (8), Critical Debates (11), Role Playing (12), Exam Teams (7), Puzzles (6), Case Studies (11), Structured Problem Solving (6) and Collaborative Writing (9). The items have a Likert format, whose response options are Always, Many Times, Sometimes, Few Times and Never, with a path of 5 to 1 , all of which are positive items. The scale is located in the annex.

\subsection{Procedure}

For the design of the scale, an extensive bibliographical review was carried out

Table 1. Characteristics of the sample.

(a)

\begin{tabular}{ccc}
\hline & Gender & \\
\hline Male & Female & Total \\
\hline $25 \%(50)$ & $75 \%(150)$ & $100 \%(200)$ \\
\hline
\end{tabular}

(b)

\begin{tabular}{ccccc}
\hline \multicolumn{5}{c}{ Age } \\
\hline Average & Median & Mode & Minimum & Maximum \\
\hline 32.61 & 30 & 25 & 23 & 65 \\
\hline
\end{tabular}


on the collaborative learning construct and its classical and contemporary exponents, being chosen the theoretical reference model to Barkley, Cross and Major (2005). The construct teaching strategies for the development of the scale was chosen, which includes in itself the constructs teaching strategies and learning strategies. Teaching and learning strategies were delineated to those that promoted collaborative learning, selecting 9; each of which was represented by a subscale of those that make up the EEDAC. They were conceptually and operationally defined and indicators were derived to point the presence of each strategy. According to the indicators, the items were written. Because of the characteristics the construct, the EEDAC consists only of positive items that refer only to the presence of indicators of the use of strategies.

Likewise, the items were submitted to the judgment of three experts to assess the content validity before the application. The reliability of the evaluations made by the judges was assessed using the index proposed by Hernández Sampieri, Fernández-Collado, \& Baptista Lucio (2010): reliability = total number of agreements/total number of coded analysis units, which is acceptable when exceeds the score of .85 . The reliability index was calculated by strategy and 3 pairs of judges were formed: JAyB, JAyC and JByC. In the same way the total reliability was obtained, product of the sum of the reliabilities of the three pairs divided by 3 .

A total of 200 scales were then applied to subjects with the characteristics already indicated in the participants section. The application was self-administered and the specific instructions given to the participants can be read in the Annex, in which the EEDAC is located. Once the scales were applied, the subjects' responses were coded, puncturing 5 for the response category Always, 4 for Many times, 3 for Sometimes, 2 for Few times and 1 for Never. In the case of items that were not answered, a score of 3 was assigned, which is the average score to be obtained.

Regarding the evaluation of the construct validity and identification of the grouping of the items of each subscale of the EEDAC, an exploratory factorial analysis (EFA) was made. The method of principal component analysis (PCA) was applied as extraction method. To evaluate the reliability of the scale, an inter-item reliability analysis was performed with the Cronbach's alpha (Cronbach, 1951). Both construct validity and reliability analysis was performed for each subscale, since in the case of different strategies, it was decided to consider each subscale as an independent scale and to verify its psychometric properties separately.

\section{Results}

The first objective of the study was to design a set of subscales with Likert-type items, each one evaluating the frequency of use of a teaching strategy for collaborative learning in the classroom. In relation to this and the evaluations of the validity of content made by the three experts in the subject (judges), three items 
were detected that where two judges disagreed with their content validity, so it was decided to eliminate them and not integrate them on the scale.

The results obtained in the total reliability index of the subscales were greater than .85 , that is, acceptable (Hernández Sampieri, Fernández-Collado, \& Baptista Lucio, 2006), in each of the subscales. Objectives 2 and 3 aimed to assess the psychometric properties of the scale, so that the EFA was carried out in the first place to generate evidence of construct validity. As part of the EFA, the Barlett sphericity test $(1950,1951)$ was applied to ensure that the correlation matrix of each subscale was significant $(p<.05)$ and to be able to reject the hypothesis of independence of the variables. The Kaiser-Meyer-Olkin (KMO) sample adequacy measures were also obtained by subscale. The values obtained in the KMO index and in the Bartlett test are shown in Table 2.

In order to be acceptable, the KMO index should be higher than .5 (Kaiser, cited by Hoffmann, 2008) and with respect to the data obtained in the KMO sample adequacy measures of the 9 subscales, the viability of the factor analysis is observed. Likewise, the Barlett sphericity test in each subscale is statistically significant $(p<.05)$, which leads to the rejection of the hypothesis of independence of the variables and it deduces that it is appropriate to continue with the factorial analysis. In sum, both values, KMO and Barlett, fully justify the application of exploratory factor analysis. When selecting the number of factors, the K1 Rule (Guttman, 1954; Kaiser, 1960) and the Cattell Sedimentation Chart (1969) were used as the basis for the exploratory factor analysis.

This study seeks to verify the unifactorial structure of each subscale, as shown in Table 3, the suggested number of factors by the eigenvalue criterion greater than 1 (rule K1) is one factor for all subscales except for Circle of Ideas and Critical Debates. The EFA of the subscales Wheel of Ideas and Critical Debates suggested the presence of three and two factors, respectively. So we proceeded to re-apply the EFA using PCA extraction method, but now fixing a fixed number

Table 2. KMO and Barlett sphericity test.

\begin{tabular}{ccccc}
\hline Subscale & & \multicolumn{3}{c}{ Barlett sphericity test } \\
\cline { 5 - 6 } & KMO & $\mathrm{X}^{2}$ & $\mathrm{gl}$ & $p$ \\
\hline Circle of ideas & .690 & 305.388 & 15 & .000 \\
Conversations groups & .845 & 570.581 & 28 & .000 \\
Critical debates & .901 & 1563.210 & 55 & .000 \\
Role playing game & .937 & 2000.531 & 66 & .000 \\
Test teams & .889 & 839.737 & 21 & .000 \\
Puzzle & .920 & 1079.378 & 15 & .000 \\
Case studies & .933 & 1646.364 & 15 & .000 \\
Structured problem solving & .905 & 823.252 & 15 & .000 \\
Collaborative writing & .937 & 1888.203 & 36 & .000 \\
\hline
\end{tabular}

Source: own elaboration. 
Table 3. Percentage variance explained and factorial loads by subscale.

\begin{tabular}{cccc}
\hline Subscale & Eigenvalues & Percentage variance explained & Factorial loads \\
\hline Circle of ideas & 2.719 & $27.19 \%$ & $.379-.703$ \\
Conversations groups & 3.534 & $48.88 \%$ & $.672-.761$ \\
Critical debates & 6.225 & $56.59 \%$ & $.603-.803$ \\
Role playing game & 7.854 & $65.45 \%$ & $.560-.756$ \\
Test teams & 4.575 & $65.35 \%$ & $.733-.870$ \\
Puzzle & 4.625 & $77.09 \%$ & $.746-.931$ \\
Case studies & 7.030 & $63.91 \%$ & $.727-.833$ \\
Structured problem solving & 4.303 & 71.71 & $.818-.841$ \\
Collaborative writing & 6.826 & 75.84 & $.819-.914$ \\
\hline
\end{tabular}

Source: own elaboration.

of factors to extract. As expected, each subscale measures a factor (that is, the strategy it measures), the number 1 was assigned. The percentage of the variance that is explained by a factor, and the factorial loads of the items in each subscale are shown in Table 3. For the analysis of each factor, only it considered those items whose saturation was greater or equal to .40 , according to the inclusion criteria proposed by Hair, Anderson, Tatham, \& Black (1999). In Table 3, the factor loads are indicated with an asterisk $\left(^{*}\right)$ which shows that it is impossible to include his item in the factor.

In the Circle of ideas subscale, the two items with factor loads less than .40 were eliminated (I ask my students to form a circle to start the activity and I indicate to my students that they must answer with a word, expression or a short statement), and the EFA was again made with the aforementioned extraction method. In the new EFA evidence of viability was obtained $(\mathrm{KMO}=.71, \mathrm{X} 2=$ $253.15, \mathrm{df}=28, p=.000)$. The variance explained by the factor was 35.05 , with an eigenvalue of 2.56 and, as expected, the ranges of factorial loads increased (.449- .746).

Now when analyzing the reliability of the subscales using the Cronbach's alpha, it observed the correlation of each item with the total of the subscale to which it belongs. This represents the discrimination index to determine whether or not to delete the item. That is, this value indicates what would be the value of Cronbach's alpha if the item is deleted. Thus, the items whose scores obtained in the column "alpha if the item is deleted are eliminated" is greater than the Cronbach's alpha value of the subscale in its entirety. In the case of the Circle of Ideas subscale, Cronbach's alpha was obtained once the items with loads less than .40 were eliminated. Table 4 shows the Cronbach's alpha values by subscale.

\section{Conclusion}

This research emerged from the interest of deepening the study of the application 
Table 4. Cronbach's alpha by subscale.

\begin{tabular}{cc}
\hline Subscale & Crobach's alpha \\
\hline Circle of ideas & .672 \\
Conversations groups & .846 \\
Critical debates & .923 \\
Role playing game & .952 \\
Test teams & .910 \\
Puzzle & .939 \\
Case studies & .943 \\
Structured problem solving & .905 \\
Collaborative writing & .960 \\
\hline
\end{tabular}

Source: own elaboration.

of strategies of collaborative learning in the classroom. Regarding the objective of developing subscales that measured the frequency of use of teaching strategies, it was found that, as a result of the content evaluation of the items by expert judges, the reliability of the content evaluations was acceptable; it followed that the analysis of content by the judges was adequate. After the content evaluation, the scale was applied to a sample for the evaluation of its psychometric properties and it was affirmed that there was evidence of construct validity, through the EFA. Rule K1 indicated that one factor was the one recommended for each, which was congruent, since each measured the frequency of use of a single collaborative learning teaching strategy. As shown in Table 3, the factor loadings of the items are adequate for each factor of the EEDAC.

Following in the same line, reliability was also evaluated. According to De Villes (2003), the internal consistency indexes obtained in all the subscales were interpreted as very good, except for Circle of Ideas, which obtained a minimally acceptable reliability. The results obtained show the achievement of the objectives and provide evidence that the Teaching Strategies Scale for Collaborative Learning (EEDAC) is a scale that has acceptable psychometric properties that can contribute to future research related to the subject when performed in environments and similar conditions in Mexico. Thus, the main contribution of this study is to provide researchers in educational psychology a reliable and valid scale, especially those interested in collaborative work.

The theoretical framework in relation to the adequate application of strategies of collaborative learning by the teachers in the classroom is scarce. Therefore, it is considered that the present study will serve as a push for the knowledge of the same and its application in the classroom. However, it is recommended to have special care in the Circle of Ideas strategy, since its reliability is not very good and the factor analysis reports the presence of three factors in a first solution. This points out that the characteristics of such a strategy could be interpreted as different strategies. This could be due to the fact that the Circle of Ideas is par- 
ticularly similar to the Storm of Ideas and this strategy is not related to collaborative learning since it can be done individually. Because the EEDAC contains only collaborative learning strategies, the activities carried out by the teacher in order for the student to learn are left out but are more related to meaningful learning (Méndez \& González, 2012).

\section{Conflicts of Interest}

The authors declare no conflicts of interest regarding the publication of this paper.

\section{References}

Álvarez Álvarez, C., \& San Fabián Maroto, J. L. (2012). La elección del estudio de caso en investigación educativa. Gazeta de Antropologia, 28. http://hdl.handle.net/10481/20644

Benemérita Universidad Autónoma de Puebla (BUAP) (2007). Modelo EducativoAcadémico.

Chan, Z. C. Y. (2012). Role-Playing in the Problem-Based Learning Class. Nurse Education in Practice, 12, 21-27. https://doi.org/10.1016/j.nepr.2011.04.008

De Oca Recio, N. M., \& Manchado Ramirez, E. F. (2011). Estrategias docentes y métodos de enseñanza-aprendizaje en la Educación Superior. Humanidades Médicas, 11. http://humanidadesmedicas.sld.cu/index.php/hm/article/view/127/81

Díaz De Salas, S. A., Mendoza Martínez, V. M., \& Porras Morales, C. M. (2011). Una guía para la elaboración de estudios de caso. Razón y Palabra, 16. http://www.redalyc.org/articulo.oa?id=199518706040

Instituto Politécnico Nacional (IPN) (2004). Un nuevo modelo educativo para el IPN.

Instituto Tecnológico y de Estudios Superiores de Monterrey (ITESM) (2018). Modelo Educativo TEC 21.

Khan, S. (2012). The One World Schoolhouse: Education Reimagined. New York, NY: Twelve.

Maldonado Pérez, M. (2008). Aprendizaje basado en proyectos colaborativos. Una experiencia en educacion. Laurus, 14, 158-180.

http://www.redalyc.org/articulo.oa?id=76111716009

Marín-Juarros, V., Negre, F. \& Pérez, A. (2014). Construction of the Foundations of the PLE and PLN for Collaborative Learning [Entornos y redes personales de aprendizaje (PLE-PLN) para el aprendizaje colaborativo]. Comunicar, 21, 35-43.

https://doi.org/10.3916/C42-2014-03

Martinez Lirola, M., Catala Cobos, P., \& Diaz Soria, M. (2013). Aprender colaborando: Estrategias de aprendizaje colaborativo integradas en el aula universitaria. XI Jornadas de redes de investigación en docencia universitaria. https://rua.ua.es/dspace/bitstream/10045/42969/1/2013-XI-Jornadas-Redes-17.pdf

Martínez-Riera, J. R., Sanjuán-Quiles, A., Cibanal-Juan, L., \& Pérez-Mora, M. J. (2011). Roleplaying en el proceso de enseñanza-aprendizaje de enfermería: Valoración de los profesores. Cogitare Enfermagem, 16, 411-417. https://doi.org/10.5380/ce.v16i3.24216

Noh, M., \& Yusuf, S. (2018). Collaborative Learning Technique within Higher Learning Education Students. Creative Education, 9, 2367-2375.

https://doi.org/10.4236/ce.2018.914177

Organisation for Economic Co-operation and Development (OECD) (2017). Education at 
a Glance 2017: OECD Indicators. Paris: OECD. https://doi.org/10.1787/eag-2017-en

Organización de las Naciones Unidas para la Educación, la Ciencia y la Cultura (UNESCO) (2016). Incheon Declaration and Framework for Action for the Implementation of Sustainable Development Goal 4. New York: Autor.

Ramírez Montoya, M. S. (2013). Models and Teaching Strategies for Innovative Environments. Digital Editorial of the Tecnológico de Monterrey. https://repositorio.itesm.mx/handle/11285/621238

Reeve, J., \& Jang, H. (2006). What Teachers Say and Do to Support Students' Autonomy during a Learning Activity. Journal of Educational Psychology, 98, 209-218. https://doi.org/10.1037/0022-0663.98.1.209

Spiers, J. A., Williams, B., Gibson, B., Kabotoff, W., Mcllwraith, D., Sculley, A., \& Richard, E. (2014). Graduate Nurses' Learning Trajectories and Experiences of Problem Based Learning: A Focused Ethnography Study. International Journal of Nursing Studies, 51, 1462-1471. https://doi.org/10.1016/j.ijnurstu.2014.03.002

Storch, N. (2005). Collaborative Writing: Product, Process, and Students' Reflections. Journal of Second Language Writing, 14, 153-173.

https://doi.org/10.1016/j.jslw.2005.05.002

United Nations Economic Commission for Latin America and the Caribbean (ECLAC) (2018). About Education.

https://www.cepal.org/en/topics/education/about-education

Universidad Autónoma de Baja California (UABC) (2013). Modelo educativo de la $U A B C$.

Universidad Autónoma de Nuevo León (UANL) (2008). Modelo Educativo de la UANL. 


\section{Appendix}

\section{Escala de Estrategias Docentes de Aprendizaje Colaborativo (EEDAC)}

Scale of Teaching Strategies for Collaborative Learning (EEDAC)

Instrucciones: A continuación se te presentan 9 series de ítems sobre estrategias docentes que pudieras utilizar para promover el aprendizaje colaborativo en tus estudiantes, así como las siguientes opciones de respuesta:

\begin{tabular}{ccccc}
\hline $\begin{array}{c}\text { Siempre } \\
(\mathrm{S})\end{array}$ & Muchas Veces & A Veces & Pocas Veces & Nunca \\
$(\mathrm{MV})$ & $(\mathrm{AV})$ & $(\mathrm{PV})$ & $(\mathrm{N})$ \\
\hline
\end{tabular}

Instructions. Below are 9 series of items on teaching strategies that you could use to promote collaborative learning in your students, as well as the following response options.

\begin{tabular}{ccccc}
\hline Always & Many times & Sometimes & Few times & Never \\
$(A)$ & $(M T)$ & $(S)$ & $(F T)$ & $(N)$ \\
\hline
\end{tabular}

En las columnas de la derecha, marca con una $\square$ ó $\otimes$ la frecuencia con la cual utilizas la estrategia docente que se describe. Intenta usar poco la categoría de respuesta A veces, a menos que realmente así sea tu caso. No hay respuestas correctas o incorrectas.

In the columns on the right, mark with $a \square$ or $\otimes$ the frequency with which you use the teaching strategy described. Try using the response category Sometimes, unless it is really your case. There are not correct or incorrect answers.

\begin{tabular}{lccccc}
\hline 1.-Subescala Estrategia Rueda de Ideas & S & MV & AV & PV & N \\
(1.-Subscale Strategy Wheel of Ideas) & (A) & (MT) & (S) & (FT) & (N)
\end{tabular}

1. Ante la presencia de un tema nuevo examino el conocimiento previo mediante preguntas.

(1. In the presence of a new topic, I examine prior knowledge through questions.)

2. Narro a mis alumnos el objetivo de la sesión.

(2. I tell my students the purpose of the session.)

3. Hago preguntas sobre el tema a mis alumnos por turnos.

(3. I ask questions about my subject in turn.)

4. Los motivo a participar en voz alta.

(4. I motivate them to participate out loud.)

5. Me aseguro que la mayoría participe.

(5. I make sure that the majority participates.)

6. Para que puedan contestar fácilmente comento situaciones relacionadas con la respuesta esperada.

(6. So that they can easily answer, I comment situations related to the expected response.)

7. Escucho con atención las respuestas de mis alumnos para formar la lista de ideas más sobresalientes.

(7. I listen carefully to the responses of my students to form the list of outstanding ideas.)

8. Hago un cierre haciendo énfasis en las respuestas correctas.

(8. I make a closing emphasizing the correct answers.) 
2.-Subescala Estrategia Grupos de Conversación

(2.-Subscale Strategy Conversation Groups)

1. Con el fin de profundizar respecto a un tema formo grupos donde se genere el diálogo al respecto.

(1. In order to deepen on an issue I form groups where the dialogue on the subject is generated.)

2. Una vez formados los equipos asigno el tema, las instrucciones y el tiempo límite.

(2. Once the teams are formed, I assign the subject, the instructions and the time limit.)

3.-Pido a los miembros de los equipos que intercambien ideas de acuerdo a ciertas instrucciones.

(3. -I ask the members of the teams to exchange ideas according to certain instructions.)

4.-Compruebo si los grupos están trabajando centrados en el tema.

(4.-I check if the groups are working focused on the subject.)

5. Realizo la retroalimentación oportunamente en los diversos equipos.

(5. I make timely feedback on the various equipments.)

6. Comento a mis alumnos sobre los beneficios de trabajar en equipo.

(6. I tell my students about the benefits of working as a team.)

7. Una vez realizado el trabajo en equipo reformulo la instrucción inicial de forma grupal.

(7. Once the team work is done, reformulate the initial

instruction in a group manner.)

8. Propicio el diálogo de forma grupal.

(8. I promotion the dialogue in a group way.)

3. -Subescala Estrategia Debates críticos

$\begin{array}{lllll}S & \text { MV } & \text { AV } & \text { PV } & \text { N }\end{array}$

(3.-Subscale Strategy Critical Debates)

(A) $\quad(\mathrm{MT}) \quad$ (S) $\quad$ (FT) (N)

1. Cuando la clase se trata de temas controversiales, propongo debates en el aula.

(1. When the class is about controversial topics, I propose debates in the classroom.)

2. Divido al grupo en dos equipos.

(2. Divide the group into two teams.)

3. Asigno a la mitad del grupo la defensa de cierto punto de vista. (3. Assign to the middle of the group the defense of a certain point of view.)

4. Asigno a la otra mitad del grupo, la defensa de un punto de vista opuesto.

(4. Assign to the other half of the group, the defense of an opposing point of view.)

5. Pido a los alumnos que señalen los argumentos que sustentan su punto de vista.

(5. I ask the students to point out the arguments that support their point of view.)

6. Menciono los beneficios sobre razonar en contra del propio punto de vista.

(6. I mention the benefits of reasoning against one's point of view.)

7. Si es preciso propicio la representación de la problemática mediante juego de roles.

(7. If it is necessary to facilitate the representation of the problem through role play.) 


\section{Continued}
8. Doy tiempo para que preparen sus argumentos.
(8. I give you time to prepare your arguments.)

9. Una vez presentado un argumento, los insto a preparar sus impugnaciones.

(9. Once an argument is presented, I exhort you to prepare your objetions.)

10. Cierro el debate con información teórica, confiable y válida al respecto.

(10. I close the debate with theoretical, reliable and valid

information about it.)

11. Doy oportunidad para que los estudiantes dialoguen sobre la experiencia.

(11. I give opportunity for students to discuss the experience.)

\begin{tabular}{lccccc}
\hline 4. - Subescala Estrategia Juego de Rol & S & MV & AV & PV & N \\
(4.-Subscale Strategy Role Playing) & (A) & (MT) & (S) & (FT) & (N)
\end{tabular}

1. Para que los alumnos "aprendan haciendo" utilizo el juego de rol.

(1. For the students to "learn by doing" I use the role play.)

2. Divido los equipos en 4 y 6 miembros.

(2. I divide the teams into 4 and 6 members.)

3. Asigno los roles o sugiero la elección voluntaria.

(3. Assign roles or suggest voluntary choice.)

4 Preparo al alumno dándole algunos consejos para que represente su rol.

(4. I prepare the student by giving him some advice to represent his role.)

5. Otorgo cierto tiempo para la preparación de la representación.

(5. I give some time for the preparation of the representation.)

6. Verifico que cada integrante del equipo esté trabajando.

(6. Verify that each member of the team is working.)

7. Solicito la representación de la problemática en cierto límite de tiempo.

(7. I request the representation of the problem in a certain time limit.)

8. Promuevo el dialogo.

(8. I promote the dialogue.)

9. Les pido que intercambien su rol para que entiendan la situación desde otra perspectiva.

(9. I ask you to exchange your role so that they understand the situation from another perspective.)

10. Pregunto al grupo sobre las acciones y consecuencias de cada rol.

(10. I ask the group about the actions and consequences of each role.)

11. Relaciono el juego de rol con el contenido teórico de la clase.

(11. I relate the role play with the theoretical content of the class.)

12. Considero la posibilidad de pedir a los alumnos que vuelvan a representar el juego de rol redefiniendo la escena en función del aprendizaje.

(12. I consider asking students to re-enact the role play by redefining the scene based on learning.) 
5. -Subescala Estrategia Equipos de exámenes

(5.-Subscale Strategy Exams Teams)

1. Formo equipos de estudio con los alumnos.

(1. I form study teams with the students.)

2. Explico a los alumnos las instrucciones para realizar esta actividad.

(2. I explain to the students the instructions to carry out this activity.)

3. Profundizo sobre los temas que se van a analizar en grupo para el examen.

(3. Deepen on the topics that will be analyzed in group for the exam.)

4. Pido a los alumnos que estudien los temas relacionados con el contenido en conjunción con sus compañeros.

(4. I ask the students to study the topics related to the content in conjunction with their classmates.)

5. Asigno un tiempo de la hora clase para el análisis de los contenidos.

(5. I assign a time of the class for the analysis of the contents.)

6. Superviso que realmente se esté llevando a cabo la actividad.

(6. I supervise that the activity is actually taking place.)

7. Administro el examen individual a los estudiantes y lo recojo para calificarlo.

(7. I administer the individual exam to the students and I pick it up to rate $i t$.)

\section{6. -Subescala Estrategia Rompecabezas}

(6. -Subscale Strategy Puzzle)

1. Para la comprensión de un tema (o temas) formo equipo de expertos.

(1. For the understanding of a topic (or topics) I form a team of experts.)

2. Listo los temas (o las secciones de un tema) para que los alumnos acorde con su nivel de dominio seleccionen uno.

(2. Ready the subjects (or the sections of a topic) so that the students according to their level of domain select one.)

3. Una vez formado los equipos de expertos les indico que deben discutir en sus grupos dicho contenido hasta dominarlo.

(3. Once formed the teams of experts indicated that they should discuss this content in their groups until they master it.)

4. Sugiero que los grupos de expertos decidan cuál será la mejor forma de transmitir dicho contenido a sus compañeros.

(4. I suggest that the groups of experts decide on the best way to transmit this content to their classmates.)

5. Los estudiantes de cada grupo pasarán a un nuevo grupo donde cada uno será el único experto en dicho tema.

(5. The students of each group will move to a new group where each one will be the only expert in that topic.)

6.-Insto a los alumnos a reflexionar sobre lo aprendido.

(6. -I promote in the students to reflect on what they have learned.)

7.-Subescala Estrategia Estudios de casos

(7.-Subscale Strategy Case Studies)

S MV AV PV N

(A) $\quad(\mathrm{MT}) \quad(\mathrm{S}) \quad(\mathrm{FT}) \quad(\mathrm{N})$
S MV AV PV N

(A) $\quad(\mathrm{MT}) \quad$ (S) $\quad(\mathrm{FT}) \quad(\mathrm{N})$




\section{Continued}

1. Cuando busco la aplicación concreta del contenido revisado en clase hago que mis alumnos analicen casos.

(1. When I search for the concrete application of the revised content in class I have my students analyze cases.)

2. Investigo cuál es el mejor caso (real o ficticio), al respecto de un tema que deseo enseñar.

(2. I investigate which is the best case (real or fictitious), about a topic that I want to teach.)

3. Llamo la atención sobre un tema narrando a mis alumnos un caso.

(3. I call attention to a topic by telling my students a case.)

4. Formo equipos de análisis del caso.

(4. Form case analysis teams.)

5. Distribuyo el caso por equipos preparado con preguntas para fomentar el análisis.

(5. Distribute the case by teams prepared with questions to promote analysis.)

6. Incito a los alumnos a la generación de ideas.

(6. I promote in students to generate ideas.)

7. Pido a los alumnos alternativas eficaces para la resolución de las preguntas del caso.

(7. I ask the students for effective alternatives for resolving the questions in the case.)

8. Motivo a los alumnos a buscar alternativas para resolver el caso en la información teórica que poseen.

(8. Motivate the students to look for alternatives to solve the case in the theoretical information they have.)

9. Solicito a los alumnos que realicen búsquedas en la web o en otras fuentes sobre aspectos desconocidos del caso.

(9. I ask students to search the web or other sources about unknown aspects of the case.)

10. Una vez contestadas las respuestas, las someto a discusión en el grupo.

(10. Once the answers are answered, I submit them to the group for discussion.)

11. Hago cierre de la actividad relacionando el caso con la información teórica.

(11. I close the activity by relating the case with the theoretical information.)

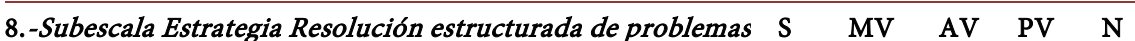

(8.-Subscale Strategy Structured problem resolution)

(A) $\quad(\mathrm{MT}) \quad(\mathrm{S}) \quad(\mathrm{FT}) \quad(\mathrm{N})$

1. Presento a los alumnos problemas complejos que lleven a la aplicación de la teoría.

(1. I present the students with complex problems that lead to the application of the theory.)

2. Formo equipos para la resolución del problema.

(2. Form teams to solve the problem.)

3. Pido a los alumnos que analicen las características de la problemática.

(3. I ask the students to analyze the characteristics of the problem.) 


\section{Continued}

4. Solicito a los alumnos que apartir de la problemática seleccionen la estrategia para solucionarlo.

(4. I ask students to share the problem to select the strategy to solve it.)

5. Comento a los alumnos sobre la utilización de estrategias adquiridas en otros momentos (o en otras asignaturas).

(5. I comment to the students about the use of strategies acquired at other times (or in other subjects).)

6. Pido a los alumnos que expongan la solución al problema explicando las estrategias utilizadas.

(6. I ask the students to explain the solution to the problem explaining the strategies used.)

\section{9. -Subescala Estrategia Escritura colaborativa}

(9.-Subscale Strategy Collaborative Writing)

1. Con el fin de que mejoren su redacción formo equipos de escritura.

(1. In order to improve their writing I form writing teams.)

2. Formo equipo de 2 o 3 integrantes.

(2. I form a team of 2 or 3 members.)

3. Explico las fases del trabajo de redacción.

(3. I explain the phases of the writing work.)

4. Establezco plazos provisionales para ayudar a los equipos a estructurar el proceso de redacción.

(4. I set tentative deadlines to help teams structure the writing process.)

5. Comento a mis alumnos los beneficios de esta técnica de redacción.

(5. I tell my students the benefits of this writing technique.)

6. Pido a los alumnos que se apoyen entre sí.

(6. I ask the students to support each other.)

7. Reviso cada etapa de avances.

(7. I review each stage of progress.)

8. Solicito que cada alumno hable sobre su aprendizaje en relación a la redacción.

(8. I request that each student talk about their learning in relation to the writing.)

9. Pregunto en qué forma se ha favorecido el aprendizaje del contenido.

(9. I ask how the learning of the content has been favored.) 